\title{
CONSTITUTIONAL LAW: INCREASED SENTENCE AND DENIAL OF CREDIT ON RETRIAL SUSTAINED UNDER TRADITIONAL WAIVER THEORY
}

\begin{abstract}
$T$ The apparent retroactive application of the Supreme Court decision $^{1}$ extending the right to counsel to defendants in state criminal proceedings provoked a flood of petitions from indigent prisoners ${ }^{2}$ and protest from many state and local officials. ${ }^{3}$ The possibility of an increased sentence and denial of credit for time served, however, remained a caveat to prisoners considering application for new trial on the basis of prior denial of counsel. The North Carolina Supreme Court in State $v$. White $e^{4}$ has rejected novel constitutional objections to the imposition of additional punishment resulting upon retrial.
\end{abstract}

The defendant in White had been denied counsel in 1961, convicted, and sentenced to ten years. Two years later he successfully sought review under the state post-conviction hearing law. ${ }^{5}$ At his

${ }^{2}$ Gideon v. Wainwright, 372 U.S. 335 (1963). The decision has been given retroactive effect in several cases. E.g., United States ex rel. Craig v. Meyers, 329 F.2d 856 (3d Cir. 1964); In re Palmer, 371 Mich. 656, 124 N.W.2d 773 (1963). The Court's language in Gideon suggests that it should be applied retroactively, 372 U.S. at 344. Moreover, cases pending at the time of Gideon were remanded for consideration on the basis of that decision. E.g., Pickelsimer v. Wainwright, 158 So. 2d 135 (Fla. 1963), remanded from 375 U.S. 2 (1963).

${ }^{2}$ In North Carolina over 660 prisoners had applied for new trials by October 1963, on the ground that they were denied counsel. See News \& Observer (Raleigh), Oct. 31, 1963, p. 38, col. 4. During the period from January 1, 1963, to March 1, 1964, 77 new trials had been awarded under the post-conviction hearing law on the basis of denial of counsel, and 121 petitions were pending on March 1, 1964. North Carolina Department of Justice Press Release, Raleigh, Aug. 15, 1964. In Florida at the date of Gideon over $50 \%$ of the inmates in prison had been convicted without counsel. Of this group over 5500 had filed petitions seeking review within 20 months of the decision. See Time, Jan. 22, 1965, p. 62.

${ }^{8}$ See Lewis, Supreme Court Ruling Steps Up Legal Aid for Poor Defendants, N.Y. Times, June 30, 1963, § 1, p. 39, col. 1. But see, N.Y. Times, Nov. 22, 1964, § 4, p. 10, cols. 4-5. Critics have particularly objected to the expenditure of funds and time and the unavailability of evidence and witnesses for new trials. See, e.g., Addresses by Judges Hall and McKinnon, Conference of North Carolina Superior Court Judges, Oct. 25, 1963, on file at Institute of Government Library, Chapel Hill, North Carolina.

4262 N.C. 52, 136 S.E.2d 205 (1964), cert. denied, 379 U.S. 1005 (1965).

- N.C. Gen. Stat., $\$ \S 15-217$ to -222 (Supp. 1963). The post-conviction hearing law is the proper state remedy for review of constitutional questions rather than a state habeas corpus proceeding. The law provides a remedy for imprisoned persons who, because of factors beyond their control, have been deprived of their constitutional rights at the original trial.

The right of direct appeal from the original conviction is also available. N.C. GEN. 
new trial he was again convicted and sentenced to twelve to fifteen years. The record did not disclose whether he was denied credit for two and one-half years served in prison. On appeal, the supreme court affirmed the new sentence, thereby rejecting the defendant's contention that the exercise of his right to review the original conviction had been unduly inhibited in violation of the fourteenth amendment. ${ }^{\circ}$

Where a new trial results in a sentence increasing the punishment imposed by an earlier conviction, one of two theories has been traditionally used to meet constitutional objections. The court in White stated that a defendant seeking a new trial is dcemed to waive all consequences of the prior procecding, accepting the hazards as well as the benefits of the new trial. ${ }^{7}$ Other courts have considered the first trial void, a nullity, thus imposing no limitation upon the second trial. ${ }^{8}$ In recognizing that there may be valid reasons for an increased sentence, ${ }^{9}$ due process is said to be satisfied if the new

STAT., $\$ \$ 15-180$ (1953). In State v. Graves, 251 N.C. 550, 112 S.E.2d 85 (1960), this right was construed to be unqualified and absolute, so long as exercised within the time to perfect the appeal.

- Brief for Appellant, pp. 4-5. The court's holding was without reservation, save for the intimation that if there had been a showing that the trial judge increased the sentence solely because the defendant obtained a new trial, it would have bcen a denial of due process. 262 N.C. at 53, 186 S.E.2d at 206 (1964). A per curiam decision on substantially identical facts four months earlier indicated no reservations. State v. Williams, 261 N.C. 172, 184 S.E.2d 163 (1964).

262 N.C. at 53, 136 S.E.2d at 206; accord, Trono v. United States, 199 U.S. 521, 538-34 (1905); State v. Terreso, 56 Kan. 126, 42 Pac. 354, 355 (1895). But see United States v. Castner, 3 U.S.C.M.A. 466, 13 C.M.R. 22 (1953). No military court on new trial may impose a sentence more severe than that originally adjudged by a lawful court in the same case. 10 U.S.C. § 863 (1958); MaNual For CourTs-Martial, UNited STATES, I $109 \mathrm{~g}(2)$ (1951).

See generally Whalen, Resentence Without Credit for Time Served: Unequal Prolection of the Laws, 35 MiNN. L. REv. 239, 240-44 (1951).

${ }^{8}$ See, e.g., Minto v. State, 9 Ala. App. 95, 64 So. 369 (1913); Hobbs v. State, 231 Md. 533, 191 A.2d 238, cert. denied, 375 U.S. 914 (1963). The effect is the same whether the defendant is deemed to waive his rights, or whether the original trial is considered void.

Many courts characterize those situations not requiring a new trial but only resentencing as merely "erroneous" rather than "void" (e.g., excessive sentence, incorrect place of incarceration, etc.). The origin of the void-erroneous concept in habcas corpus proceedings and its application to double jeopardy is set forth in Whalen, supra note 7, at 240-44. The distinction has been carried over to the MODEL PENAL CODE $\$ 7.09$ (Proposed Official Draft, 1962), but is now rejected in the federal courts which characterize all situations as waiver. Tinkoff v. United States, 86 F.2d 868, 874 (7th Cir. 1936). Compare King v. United States, 98 F.2d 291 (D.C. Cir 1988). with United States v. Harman, 68 Fed. 472 (D. Kan. 1895).

- See text accompanying note 38 infra. 
sentence alone, ${ }^{10}$ or the new sentence plus the previous confinement, ${ }^{11}$ does not exceed the statutory maximum for the offense.

The waiver theory has also been applied to justify a majority rule that the defendant who obtains a new trial is not entitled to credit for time served under the original sentence. ${ }^{12}$ No court has found a constitutional requirement that credit be allowed for time served. ${ }^{13}$ A minority of jurisdictions do, however, grant credit with ${ }^{14}$ or without $^{15}$ statutory authorization on the ground that "glaring and intolcrable injustice would result if the time served on a first sentence should not be taken into account in imposing a second sentence."16

${ }^{20}$ Hobbs v. State, 231 Md. 533, 191 A.2d 238, cert. denied, 375 U.S. 914 (1963). In State v. Williams, 261 N.C. 172, 134 S.E.2d 163 (1964), the defendant, having served time previously under a conviction without benefit of counsel, was sentenced to the maximum of ten years on retrial. Thus it would scem that in North Carolina due process is satisfied if the new sentence alone conforms to the statutory rule.

${ }^{11}$ See, e.g., In re Leypoldt, 32 Cal. App. 2d 518, 90 P.2d 91 (1939) (resentence void as to excess of statutory maximum including time served); cf. De Benque v. United States, 85 F.2d 202 (D.C. Cir. 1936); Koslowski v. Board of Trustees, 118 Atl. 596 (Del. Super. 1921); Little v. Wainwright, 161 So. 2d 213 (Fla. 1964). But cf. Ex parte Fritz, 179 Cal. 415, 177 Pac. 157 (1918) (dictum).

The situation in Whitc would satisfy either line of authority, because the second sentence was well within the statutory limitation of thirty years, and the combination of prior time served plus the new sentence would also be within this maximum. However, the court suggested that the defendant could have been sentenced to the statutory maximum, 262 N.C. at 56, 136 S.E.2d at 207 , which would be in accord with the rule derived from State v. Williams, supra note 10.

12 E.g., McDowell v. State, 225 Ind. 495, 76 N.E.2d 249 (1947); Ex parte Wilkerson, 76 Okla. Crim. 204, 135 P.2d 507 (1943).

In cases involving resentencing without a new trial the courts are not in agreement on the question whether time served on a first sentence is to be credited against time served on the second. Compare In re Leypoldt, 32 Cal. App. 2d 518, 90 P.2d 91 (1939), with Minto v. State, 9 Ala. App. 95, 64 So. 369 (1913). In this situation, the majority view is that credit is proper, In re Leypoldt, supra, and North Carolina does adopt this view. E.g., State v. Searcey, 251 N.C. 320, 111 S.E.2d 190 (1959); State v. Austin, 241 N.C. 548, 85 S.E.2d 924 (1955).

${ }^{13}$ Compare Ex parte Wilkerson, supra note 12 (no constitutional power in the court to allow credit). It has been suggested that imposition of a sentence without allowance of credit is a violation of the equal protection clause of the fourteenth amendment, but no court has accepted this argument. See Whalen, supra note 7 , at 251.

1* See, e.g, CAL. PEN. CODE § 2900.1; In re James, 38 Cal. 2d 302, 240 P.2d 596 (1952); cf. Manual for Courts-Martial, United States, f 109 (1) (1951). Other state statutes are cited in Agata, Time Served Under a Reversed Sentence or Conviction-A Proposal and a Basis for Decision, 25 MoNT. L. REv. 3, 65-68 (1963). But cf. State ex rel. Nelson v. Ellsworth, 141 Mont. 78, 375 P.2d 316 (1962), where the court interpreted a Montana law as forbidding credit in certain situations.

${ }^{25}$ In re Wilson, 202 Cal. 341, 260 Pac. 542 (1927); Little v. Wainwright, 161 So. 2d 213 (Fla. 1964); Ex parte Williams, 63 Okla. Crim. 395, 72 P.2d 904 (1938); Stonebreaker v. Smyth, 187 Va. 250, 46 S.E.2d 406 (1948).

${ }^{10}$ Lewis v. Commonwealth, 329 Mass. 445, 447-48, 108 N.E.2d 922, 923 (1952). 
The court in White reiterated the traditional bases supporting increased sentence and denial of credit without expressly considering a new due process objection advanced by the defendant. While conceding the absence of any constitutional requirement that the states provide procedures for criminal appeal, ${ }^{17}$ the defendant insisted that the Constitution does require machinery for review and correction of substantial federal constitutional defects. ${ }^{18}$ Although North Carolina had provided the means for correction of constitutional deprivations, ${ }^{19}$ the defendant contended that a state is prohibited from attaching "a condition or consequence to the exercise of a right" conferred by the Constitution where the effect is to circumscribe and inhibit its free exercise. ${ }^{20}$ The possibility of intimidation presented by "punishing" defendants for electing the right to obtain post-conviction relief was urged as an unreasonable condition tending to coerce defendants into surrendering a constitutional right of review. ${ }^{21}$

The North Carolina Supreme Court has long recognized that the authority to increase sentences might be purposely and improperly employed to discourage appeals. ${ }^{22}$ In one such case, ${ }^{23}$ defendant had

\footnotetext{
${ }^{17}$ See Griffin v. Illinois, 351 U.S. 12, 18-20 (1956); Young v. Ragen, 337 U.S. 235 (1949); United States v. St. Glair, 42 F.2d 26, 28 (8tl Cir. 1930).

${ }_{18}$ Accord, Mooney v. Holohan, 294 U.S. 103 (1935); Frank v. Mangum, 237 U.S. 309 (1915). In Mooney, altlough the defendant's appeal was dismissed for the failure to exhaust state remedies, the Court held that it is the duty of every state to provide corrective judicial process for persons convicted without due process of law. Frank, on the other hand, stated that the Constitution does not impose any particular pro. cedure for the redress of constitutional deprivations, but nevertheless requires the essential right of notice and hearings before a "competent tribunal." Thus, where federal issues are involved and the state has no procedure to correct errors of federal law, a defendant may vindicate his federal rights by federal habeas corpus. Jennings v. Illinois, 342 U.S. 104 (1951); see Young v. Ragen, supra note 17.

${ }^{10}$ N.C. GeN. STAT. $\$ 15-180$ (1953) (appeal); N.C. GeN. STAT. $\$ \$ 15-217$ to -222 (Supp. 1963) (post convictions hearings). Defendant White used the latter remedy because the time to perfect direct appeal had expired, and habeas corpus was available only after the post-conviction hearing law had been utilized. See State v. Graves, 251 N.C. 550, 112 S.E.2d 85 (1960). See also Habeas Corpus Proceeding Instituted By Prisoners Confined and in the State Prison System, North Carolina Department of Justice Press Release, Raleigh, Jan. 1, 1964, pp. 3-4.

20 Brief for Appellant, p. 5.

21 Id. at 4-6. The alleged intimidation had not prevented the defendant in White from exercising his right to a post-conviction hearing, hence it is arguable that he had no standing to assert the deprivation of other prisoners' rights. Nevertheless, the parties whose rights are impaired would not present their grievance before any court, and in such cases the Supreme Court has disregarded the standing requirement to vindicate fundamental rights. Barrows v. Jackson, 346 U.S. 249, 257 (1953); cf. NAACP v. Alabama, 375 U.S. 449, 459 (1958).

${ }^{22}$ State v. Patton, 221 N.C. 117, 19 S.E.2d 142 (1942).

Although the defendant in White focused primarily upon a due process argument,
} 
been fined and given a suspended sentence. Upon notice of appeal, the trial judge promptly struck the suspension and sentenced the defendant to jail. In reversing, the court held that the right of appeal could not be abridged or denied, "nor should the attempt to exercise this right impose upon the defendant an additional penalty or the enlargement of his sentence." 24 The instant case did not involve an appeal, and the defendant did not intimate that the judge at his second trial had increased his sentence to discourage post-conviction relief, nor did he attempt to show that state judges were systematically increasing sentences for that purpose. ${ }^{25} \mathrm{He}$ ob-

others have considered the theory that an increased sentence violates the equal protection clause as well. See Agata, supra note 14, at 19, 21; Whalen, supra note 7, at 251.

${ }^{28}$ State v. Patton, supra note 22.

2t $I d$. at 119, 19 S.E.2d at 144 (Emphasis added.); see State v. Calcutt, 219 N.C. 545, 15 S.E.2d 9 (1941). But see Nichols v. United States, 106 Fed. 672 (8th Cir. 1901). In the latter case the court upheld the harsher sentence on the presumption that the lower court acted from proper motives. But in dictum, the court answered the contentions that the sentence was increased because the defendant gave notice of appeal by saying: "A new sentence, with enhanced punishment, based upon such a reason, would be a flagrant violation of the rights of the defendant. It would be the infliction of a penalty for the exercise of a clear legal right, and would call for the severest censure." Id. at 679 .

${ }^{25}$ This contention would be extremely difficult to prove. The results of an informal survey of North Carolina superior courts conducted by the Duke Law Journal failed to establish conclusively that trial judges were (or were not) systematically increasing sentences and denying credit. Hence it is impossible to infer from the following statistics whether defendants are in fact punished for exercising post-conviction remedies. With 59 of 100 superior courts responding, the following information was obtained:

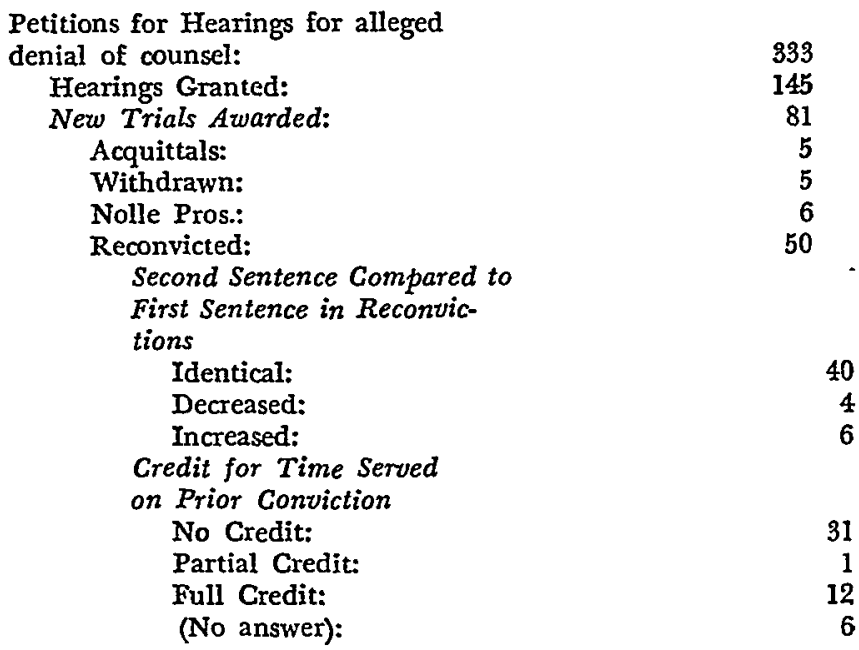

Recent cases in North Carolina which are not accounted for in the above statistics raise an inference that the courts are impatient with retrials. In one instance a defendant only months away from parole was denied credit for almost two years 
jected solely to the existence of authority to increase sentences which required him to play a game of chance in order to challenge the constitutionality of the first trial.

In cases involving the state-created right to appeal, one court has recognized that the fear of an increased sentence may unreasonably impair exercise of that right. ${ }^{28}$ The United States Supreme Court has also taken this fear into consideration when allowing federal habeas corpus without exhaustion of state remedies.27 In White, though defendant was utilizing state procedures, such procedures were required by his constitutional right of review of substantial federal constitutional defects, as distinguished from statecreated rights and privileges. Where statutes or procedures tend to impair the exercise of federal constitutional rights, the encumbrances are constitutionally proscribed. ${ }^{28}$ A state, for example, may not adopt arbitrary procedures for eliminating obscene literature without procedural safeguards to insure protection of freedom of expression. ${ }^{29}$ Nor may a city by statute automatically terminate the employment of a city employee simply because he has invoked the fifth amendment. ${ }^{30}$ Although reasonable restrictions may be im-

served in prison and his original sentence was increased by over twice as much to a minimum of seven years and a maximum of nine years. Telephone Conversation with Alton G. Murchison, III, of Levine \& Goodman, Charlotte, N.C., Counsel for Defendant on Appeal, Jan. 29, 1965. In another instance, the defendant's sentence was increased from a minimum of five and a maximum of seven years to a minimum of twelve and a maximum of twenty years. Durham Sun, Feb. 19, 1965, § B, p. 1, col. 5. Both cases will be appealed, but to date State $v$. White appears controlling.

${ }^{26}$ People v. Henderson, 60 Cal. 2d 482, 386 P.2d 677 (1963). Defendant was convicted of first degree murder and sentenced to life imprisonment. Since the trial was defective, he was retried, reconvicted, and sentenced to death. In reducing the sentence to life imprisonment, the court said that his right to appeal was unreasonably impaired: "Since the state has no interest in preserving erroneous judgments, it has no interest in foreclosing appeals therefrom by imposing unreasonable conditions on the right to appeal." Id. at 497,386 P.2d at 686 ." The same argument could be applied to post-conviction remedies.

${ }_{27}$ Fay v. Noia, 372 U.S. 391, 396-97 \& n.3, $439-40$ (1963). Defendant's failure to appeal through state procedures was excused because of a well-founded fear of receiving the death penalty on retrial. However, in remanding the case the Court imposed no limitations on the sentence of a possible new trial. In both People v. Henderson, supra note 26, and Fay, the fear of increased sentence was a fear of receiving the death penalty, and not merely an increase in confinement as in White.

${ }^{28}$ Freedman v. Maryland, 85 U.S. 734 (1965); Quantity of Books v. Kansas, 378 U.S. 205 (1964); Marcus v. Search Warrant, 367 U.S. 717, 731 (1961); Slochower v. Board of Educ., 350 U.S. 551 (1956); cf. Terral v. Burke Constr. Co., 257 U.S. 529 (1922) (statute revoking license of foreign corporation suing in, or removing to, federal court).

20 Marcus v. Search TVarrant, supra note 28 , at 781 .

${ }^{\text {so }}$ Slochower v. Board of Educ., 350 U.S. 551 (1956). Moreover, Mr. Justice Goldberg recently has questioned the constitutionality of traffic statutes which offer the accused 
pused on constitutional rights, ${ }^{31}$ in the absence of additional evidence justifying greater punishment, the possibility of increased sentence and denial of credit confer a seemingly arbitrary puwer upon retrial. Moreover, if this unduly impairs the right of postconviction relief for trials without counsel, the inhibitory effect of potential additional punishment would appear to also infringe upon the guaranteed right to counsel.

As a matter of policy, a state's interest in retaining the deterrent effect of possible increased sentence is not compelling. Courts have expressed concern for the prevention of frivolous post-conviction petitions, ${ }^{32}$ the needless waste of court time, unnecessary expenditure of public funds, ${ }^{33}$ and for the protection of the public from release of prisoners $^{34}$ because of unavailable witnesses or lost evidence. ${ }^{30}$ This attitude, however, reflects an assumption that only the unmeritorious petitioner will be discouraged. It ignores the judicial duty to cope with frivolous post-conviction remedies rather than deprive defendants of a right to counsel..$^{36}$ Implicit in the fear that lapse of time will render conviction at a new trial impossible is the assumption that those released will be hardened criminals and likely second offenders. Such an assumption has proved fanciful. ${ }^{37}$ Allow-

violator the choice of paying a fine or asking for a trial which might result in a larger fine, stating: "I am not convinced that the generally sound advice to "pay the two dollars' necessarily reflects a constitutionally permissible requirement." Marder v. Massachusetts, 377 U.S. 407 (1964) (dissenting opinion). See also Spencer v. California, 377 U.S. 1007.09 (1964) (Goldberg, J., dissenting); United States v. Tateo, 377 U.S. 463, $471-72$ (1964) (Goldberg, J., dissenting).

${ }^{81}$ See, e.g., Adler v. Board of Educ., 342 U.S. 485, $492-93$ (1952); Garner v. Board of Public Works, 341 U.S. 716, 720-21 (1951).

${ }^{2}$ See, e.g., Address by Judge McKinnon, supra note 3. "He who must search the haystack for a needle is likely to end up with the attitude that the needle is not worth the scarch," (quoting from Brown v. Allen, 344 U.S. 443, 537 (1952) (Jackson, J., concurring)).

${ }^{83}$ See Lewis, supra note 3.

st See Krash, The Right to a Lawyer: The Implications of Gideon $v$. Wainwright, 39 Notre Dame LAw. 150, 156 (1964).

${ }^{85}$ Cf. Tucker, The Supreme Court and the Indigent Defendant, 37 So. CAL. L. REv. 151, 177 (1964). In North Carolina only 13 defendants were set free out of 77 new trials awarded between January 1, 1963 and March 1, 1964. North Carolina Department of Justice Press Release, Ralcigh, August 15, 1964.

80 A federal judge, in discussing similar post-trial problems, suggests that the burden is not too heavy: "searching for and now and then finding the occasional just cause, is after all, but a part of ... [the judge's] job." Address by Judge Walter Pope, Conference of the Ninth Judicial Circuit, Santa Barbara, June 27, 1963, in Habeas Corpus and Post Conviction Review, 33 F.R.D. 363. 432 (1963). See also Tucker, supra note 35 , at 177-78; N.Y. Times, Nov 22, 1964, \$4. p. 10, cols. 4-5.

${ }^{37}$ In Florida, only $4 \%$ of those released (who numbered over 1,000 by January, 1965) had returned to a life of crime bi October, 1964. compared to a national 
ing some prisoners to go free is the price properly paid by the state for past denials of a constitutional right.

Other legitimate interests supporting increased sentences are more substantial. It is argued that allowance should be made for differences in sentencing techniques, new and damaging evidence at the second trial, ${ }^{38}$ or prison misbehavior during the first confinement. Assuming that these may be legitimate factors to be considered at the second trial, the judge should, at a minimum, be required to state the facts upon which he relies for an increase in sentence. $^{39}$ Otherwise, as in White, no aggravating factors will be articulated in the record, ${ }^{40}$ and yet the increase may in fact be imposed as a punishment for exercising the right of appeal.

In the related context of cases on appeal, the federal courts have advocated an absolute limitation upon subsequent sentencing. They assert that where a federal judge had an opportunity to rule on the sentence and exercised his discretion, if no error was committed with respect to the sentence there should be no opportunity to consider an increase. ${ }^{41}$ Although these cases did not consider the question of new trials, the same theory could be applied in the absence of new evidence justifying an increase.

In any event no tenable justification exists for the use of the waiver theory to support a denial of credit for time already served. Waiver here is a conclusion which is offered to justify a result, but which does not describe the process. ${ }^{42}$ Where one "waives" the effect of the first trial and "consents" to a new trial he does so only because

average of $65 \%$, according to a statement of Florida Prison Director Wainwright made on CBS Reports, CBS-TV, October 7, 1964.

${ }^{88}$ See People v. Henderson, 60 Cal. 2d 482, 498, 386 P.2d 677, 687 (1963) (Schauer, J., dissenting).

${ }^{80}$ See Agata, supra note 14, at 19. Another limitation on the discretion of sentencing authorities might be a presumption in favor of the correctness of the first sentence as the maximum that should be imposed, rebuttable only by clear, convincing, and compelling facts.

10262 N.C. at 55, 136 S.E.2d at 207.

1 See, e.g., Blackman v. United States, 250 Fed. 449 (5th Cir. 1918); United States v. Benz, 282 U.S. 304, 307 (1931) (dictum).

4 The waiver doctrine was originally a device created solely to prevent a defendant from claiming that a second trial, after appeal and reversal on his own motion, constituted double jeopardy. See Comley, Former Jeopardy, 35 YALE L.J. 674, 680-81 (1926).

In Green v. United States, 355 U.S. 184, 192 (1957), the Court stated that "waiver" of a constitutional right was "wholly fictional." Moreover, "it cannot be imagined that the law would deny to a prisoner the correction of a fatal error, unless he should waive other rights so important as to be saved by an express clause in the Constitution of the United States." Ibid. (quoting from Kepner v. United States, 195 U.S. 100, 135 (1904) (Holmes, J., dissenting)). 
the law imposes this as a consideration of setting aside the conviction. ${ }^{43}$ To say that the defendant has waived all consequences of the first conviction is to say that he served no sentence, but merely spent time in jail.44 Such a characterization penalizes a defendant even though it was the state's deficiency which necessitated the new trial.45

Neither the traditional fiction of waiver nor countervailing state interests justify the result obtained in White. Denial of credit on the basis of an imputed intent to waive the consequences of a first trial, as well as unexplained increases in sentence, tend to impair the exercise of constitutional rights, including the right to postconviction relief. ${ }^{46}$ The court in White should have considered a criminal procedure which would instead have insured protection for constitutional rights. ${ }^{47}$

\footnotetext{
"See Agata, supra note 14, at 20-21.

" See King v. United States, 98 F.2d 291 (D.C. Cir. 1938). The court sarcastically added that since "he was not imprisoned at all... it might be suggested that he is liable in quasi-contract for the value of his board and lodging, and criminally liable for obtaining them by false pretenses...." Id. at 293-94.

"Even the state's brief in White recognized a viable argument for credit. Brief for State, p. 3. If the arguments against denial of credit are considered valid, the problem should not be divorced from the problem of increased sentence because the judge could effectively negate any credit accumulated by increasing the sentence.

"Sce notes 18-21 supra and accompanying text.

${ }^{47}$ See Traynor, Mapp v. Ohio at Large in the Fifty States, 1962 Duke L.J. 319, $340-41$.
} 